\title{
PENGARUH PERILAKU PEMIMPIN TERHADAP KEYAKINAN BAWAHAN PADA KEPEMIMPINAN TRANSFORMASIONAL: SUATU PENDEKATAN MODEL SYNCRETICAL
}

\author{
Linawati \\ Alumnus Program Magister Sains Jurusan Manajemen \\ Universitas Gadjah Mada Yogyakarta
}

\begin{abstract}
This research is intended to analyze the influence of leader behavior on follower belief in transformational leadership based on syncretical model of charismatic/transformational leadership. There are three problems to discuss on this research: (i) What the displays empathy and dramatizes the mission of leader behavior has influence on the inspiration of follower?, (ii) What the projects self-assurence and enhances the leader's image of leader behavior has influence on the awe of follower?, (iii) What the assures followers of their competency and provides followers with opportunities to experience success of leader behavior has influence on the empowerment of follower?

The number of the respondent is 119 graduate students of Magister Management Program taken from three (3) state and private universities in Jogjakarta. The questionnaire developed by Behling and McFillen (1996) was used to collect the data. Eighteen (18) items are used to measure the variable of leader behavior and fifteen (15) items are used to measure the variable of follower belief. The data were analized by Multiple Regression Analysis.

The result of this study indicate that: (i) the displays empathy of leader behavior has a positive and significant influence on the inspiration of follower, while dramatizes the mission of leader behavior has no influence on the inspiration of follower, (ii) projects self-assurence and enhances the leader's image of leader behavior has a positive and significant influence on the awe of follower, (iii) assures followers of their competency and provides followers with opportunities to experience success of leader behavior has a positive and significant influence on the empowerment of follower.
\end{abstract}

Keywords: Leader Behavior, Follower Belief, Transformational Leadership, Syncretical Model of Charismatic/ Transformational Leadership.

\section{PENDAHULUAN}

Seiring dengan perubahan lingkungan bisnis yang sangat pesat dan tekanan-tekanan persaingan yang semakin meningkat, tuntutan untuk melakukan perubahan dalam berbagai aspek di perusahaan juga semakin meningkat. Pemimpin memiliki peranan nyata dalam membentuk pola pikir yang berfungsi sebagai simbol dari kesatuan moral bawahannya, dimana pemimpin mengekspresikan etika kerja dan nilai-nilai yang ada di organisasi. Ackoff, 1999 (dikutip dari Tjiptono \& Syakhroza, 1999) mengungkapkan bahwa kepemimpinan mencakup upaya untuk memandu, mendorong (encouraging), dan memfasilitasi orang lain dalam rangka pencapaian tujuan dengan menggunakan cara-cara tertentu, dimana tujuan dan cara tersebut ditentukan atau disepakati oleh orang-orang tersebut.

Keberhasilan perilaku pemimpin transformasional dapat diukur melalui sudut pandang penerimaan dan keyakinan bawahan. Hasil penelitian eksploratori yang dilakukan Behling dan McFillen (1996) menunjukkan bahwa dalam kepemimpinan transformasional, perilaku pemimpin yang terdiri dari displays empathy, dramatizes the mission, projects self assurance, enhances the leader's image, assures followers of competency, dan provides opportunities to experience success akan mempengaruhi keyakinan bawahan 
(terdiri dari inspiration, awe, dan empowerment). Menurut Bass dan Avolio (1994), kepemimpinan transformasional dalam mentransformasikan bawahan cenderung menggunakan 4 cara yang dikenal dengan 4 I, yaitu: 1) idealized influence (charisma), 2) inspiration, 3) intellectual stimulation, dan 4) individual consideration.

Penelitian ini dilakukan untuk menguji model syncretical kepemimpinan kharismatik atau transformasional yang disampaikan oleh Behling dan McFillen (1996). Motivasi peneliti untuk menguji model syncretical adalah untuk mengetahui apakah variabel-variabel perilaku pemimpin dan variabel-variabel keyakinan bawahan yang ada pada model syncretical tersebut dapat diterapkan atau berlaku bagi responden di Indonesia. Seringkali penelitian mengenai perilaku pemimpin dengan setting yang berbeda dapat memberikan hasil penelitian yang berbeda pula. Hasil riset kepemimpinan lintas budaya yang dilakukan Jung dan Avolio (1999) terhadap 153 Asean student dan 194 Caucasian student mengenai kepemimpinan transformasional dan transaksional mengindikasikan bahwa penerapan gaya kepemimpinan yang sama dapat diinterpretasikan berbeda dan dapat mempunyai pengaruh yang berbeda dalam motivasi dan kinerja bagi bawahan pada kelompok budaya yang berbeda. Hal ini dikarenakan bahwa pada dimensi budaya yang berbeda, setiap karakter pemimpin dan bawahan mempunyai kecenderungan sikap dan perilaku yang berlainan. Sikap dan perilaku yang berbeda tersebut pada akhirnya akan mempunyai kecenderungan untuk memberikan hasil penelitian yang berbeda terhadap suatu penelitian mengenai sikap dan perilaku.

Kebutuhan untuk melakukan penelitian ini didasarkan pada penelitian-penelitian yang sudah ada sebelumnya, dimana kepemimpinan transformasional yang dijadikan obyek penelitian pada umumnya mencakup empat dimensi kepemimpinan transformasional yang dikenal dengan $4 \mathrm{I}$ yaitu: idealized influence (charisma), inspiration, intellectual stimulation, dan individual consideration, dengan menggunakan instrumen penelitian MLQ (Multifactor Leadership Questionnaire) dengan lima skala likert yang dikembangkan oleh Bass dan Avolio pada tahun 1985, sehingga hal ini mendorong peneliti untuk menguji model syncretical yang disampaikan oleh Behling dan McFillen (1996) beserta instrumen penelitian mereka sebagai instrumen dalam penelitian ini yang dapat membedakan dengan penelitian-penelitian sebelumnya. Berdasarkan uraian-uraian di atas, maka permasalahan secara umum yang diangkat dalam penelitian ini mengacu pada penelitian sebelumnya dari Behling dan McFillen (1996), yaitu apakah atribut perilaku pemimpin (terdiri dari displays empathy, dramatizes the mission, projects self-assurance, enhances the leader's image, assures followers of their competency dan provides opportunities for followers to experience success) mempunyai pengaruh terhadap keyakinan bawahan (terdiri dari inspiration, awe, dan empowerment)?

Keberhasilan suatu organisasi akan sangat ditentukan oleh cara pengelolaan manajemen terhadap sumber daya manusia dan semua aktivitas organisasi. Peranan pemimpin dalam memahami dan memimpin bawahan yang memiliki karakteristik yang beragam akan menentukan keberhasilan organisasi di masa mendatang. Seorang pemimpin harus dapat merasakan apa yang dirasakan oleh bawahan, memahami kebutuhan dan keinginan bawahan yang diimplementasikannya dalam sikap dan perilaku sehari-hari. Selain itu, pemimpin juga mempunyai peran penting dalam menyampaikan misi, mengkomunikasikannya dan melakukan persuasi dengan bahasa serta kalimat yang dapat dimengerti oleh bawahan. Kondisi seperti ini akan menimbulkan motivasi dan semangat (menimbulkan inspirasi) untuk bekerja dengan baik karena bawahan mengetahui apa yang dikehendaki oleh perusahaan dan apa yang menjadi tujuan perusahaan tersebut. Sesuai dengan penelitian Behling dan McFillen (1996) maka permasalahan pertama yang dapat diangkat dalam penelitian ini adalah untuk membuktikan apakah displays empathy dan dramatizes the mission dari perilaku pemimpin berpengaruh terhadap inspiration bawahan?

Rasa percaya diri dan keyakinan yang kuat dalam bertindak dan berperilaku sebagai seorang pemimpin merupakan salah satu faktor yang tidak dapat dipisahkan dari kepemimpinan transformasional. Pemimpin akan memproyeksikan keyakinan dirinya untuk mengelola organisasi semaksimal mungkin dan berusaha menanamkan image yang baik kepada bawahan. Perilaku pemimpin yang bertindak dengan penuh keyakinan dan percaya diri serta dapat memberikan image yang baik kepada bawahan pada akhirnya akan menimbulkan rasa simpatik bawahan terhadap pemimpin sehingga mereka akan selalu berusaha mematuhi perintah atasannya dan bekerja secara optimal. Sesuai dengan penelitian Behling dan McFillen (1996), maka permasalahan kedua yang dapat diangkat dalam penelitian ini adalah untuk membuktikan apakah projects 
self-assurance dan enhances the leader's image dari perilaku pemimpin berpengaruh terhadap awe bawahan?

Keberhasilan bawahan dalam mencapai tujuan akan sangat ditentukan oleh perilaku pemimpin dalam mempengaruhi bawahan agar mereka termotivasi untuk meraih keberhasilan dalam pekerjaannya. Pemimpin transformasional akan memandang bawahan sebagai aset yang sangat penting bagi perusahaan, sehingga pemimpin akan berusaha meyakinkan bawahan terhadap kemampuan yang dimilikinya, berusaha memberikan motivasi dan kesempatan kepada bawahan untuk mengatasi berbagai hambatan dan berusaha meyakinkan bawahan untuk mengendalikan situasi yang dihadapinya. Pemimpin transformasional juga memberikan kesempatan kepada bawahan untuk mencapai kesuksesan dalam berkarir yaitu dengan mendelegasikan tanggung jawab dan pekerjaan kepada bawahan sehingga mereka akan berusaha mengatasi segala hambatan dengan kemampuan yang dimilikinya. Sesuai dengan penelitian Behling dan McFillen (1996), maka permasalahan ketiga yang dapat diangkat dalam penelitian ini adalah untuk membuktikan apakah assures followers of their competency dan provides opportunities for followers to experience success dari perilaku pemimpin berpengaruh terhadap pemberdayaan (empowerment) bawahan?

\section{TINJAUAN TEORI DAN HIPOTESIS}

\section{1. Displays Empathy, Dramatizes The Mission, dan Inspiration}

Pemimpin yang mempunyai empati terhadap bawahan serta mampu menyampaikan visi dan misi perusahaan dengan penjelasan yang dapat dimengerti oleh bawahan merupakan elemen krusial dalam kepemimpinan kharismatik/transformasional. Behling dan McFillen (1996) memberikan definisi operasional mengenai variabel perilaku pemimpin (displays empathy dan dramatizes the mission) dan variabel keyakinan bawahan (inspiration) sebagai berikut:

a. Displays empathy, yaitu perilaku pemimpin mengindikasikan ôrientasi pada kebutuhan dan keinginan bawahan.

b. Dramatizes the mission, yaitu pemimpin menggunakan metafora, kiasan, analogi untuk nilai-nilai dan simbol organisasi untuk menyampaikan misi dan kepentingannya. Pemimpin mengkomunikasikan misi utama melalui tindakan yang dilakukannya.

c. Inspiration, yaitu keyakinan bawahan bahwa kegiatan organisasi atau unit memiliki suatu moral transeden atau tujuan etik.

Vries (1994) mengungkapkan bahwa tidak ada pemimpin tanpa visi. Seorang pemimpin yang dapat memberi inspirasi tinggi terhadap bawahan merupakan pemimpin yang memiliki standar kerja yang tinggi dan mempunyai visi/misi yang jelas. Kesuksesan kepemimpinan transformasional adalah kemampuan menentukan misi yang jelas, mengkomunikasikannya dan melakukan persuasi kepada bawahan (Leavitt, 1986). Pemimpin mengarahkan seluruh sumber daya organisasi pada suatu fokus yaitu misi dan visi organisasi. Pengarahan sumber daya organisasi pada suatu fokus (misi dan visi) dapat menimbulkan energi luar biasa untuk mendorong kemajuan organisasi disamping faktor kesadaran leader terhadap kemampuannya untuk menyadari, memahami, memberikan dukungan, melibatkan diri, dan memberikan komitmen terhadap trend perubahan yang terjadi atau yang secara potensial akan terjadi di masa yang akan datang (Mulyadi, 1997).

Conger dan Kanungo (1987) menyatakan bahwa ciri-ciri pemimpin kharismatik adalah percaya diri, mempunyai keahlian manajemen terutama dalam mengatasi berbagai perubahan, mempunyai sensitivitas sosial dan empati. Pemimpin yang mempunyai empati terhadap bawahan (memahami keinginan dan kebutuhan bawahan) akan meningkatkan kepercayaan bawahan terhadap aktivitas organisasi, sehingga karyawan akan terinspirasi untuk melakukan pekerjaan sebaik mungkin. Burns, 1978 (dikutip dari Bass \& Avolio, 1990) menyatakan bahwa empati menunjukkan kualitas kepemimpinan yang dirasakan dan dipersepsikan seorang bawahan. Para pemimpin memiliki kekuatan dan kelemahan masing-masing yang dapat dipersepsikan bawahannya melalui rasa empati, memahami kebutuhan dan keinginan serta ketidak amanan yang dirasakan bawahannya (Bass, 1985). Pemimpin yang menunjukkan perilaku positif terhadap bawahan akan dirasakan dan dipersepsikan positif oleh bawahan. Penelitian Behling dan McFillen (1996) terhadap MBA student dan MOD students yang sudah bekerja mengungkapkan bahwa inspiration bawahan 
disebabkan oleh displays empathy dan dramatizes the mission dari perilaku pemimpin. Berdasarkan uraian diatas, peneliti mengajukan hipotesis sebagai berikut:

Hipotesis 1a : Displays empathy dari perilaku pemimpin berpengaruh secara signifikan terhadap inspiration bawahan.

Hipotesis 1b : Dramatizes the mission dari perilaku pemimpin berpengaruh secara signifikan terhadap inspiration bawahan.

\section{2. Projects Self-Assurance, Enhances The Leader's Image, dan Awe}

Rasa simpati yang dimiliki bawahan terhadap pemimpin membuat pemimpin mudah diterima oleh bawahannya dari berbagai aspek, baik dari aspek pekerjaan maupun kemampuan berorganisasi. Bass (1985) menegaskan bahwa kepercayaan (trust) bawahan merupakan konsekuensi logis dari kepemimpinan transformasional. Behling dan McFillen (1996) memberikan definisi operasional mengenai variabel perilaku pemimpin (projects self-assurance dan enhance the leader's image) dan variabel keyakinan bawahan (awe) sebagai berikut:

a. Projects self-assurance, yaitu pemimpin bertindak percaya diri dan penuh keyakinan.

b. Enhances the leader's image, yaitu perilaku pemimpin ditunjukkan dengan tindakan tindakan yang dilakukan dari kompetensi personal dan komitmen total pada misi organisasi.

c. Awe, yaitu keyakinan bawahan terhadap kemampuan pemimpin yang seringkali tidak selalu sesuai dengan pengaruhnya.

Menurut Willner (1984), dimensi kepemimpinan kharismatik meliputi kepercayaan bahwa pemimpin adalah orang yang hebat, mempunyai kekuasaan dan kemampuan, artinya bahwa pemimpin merupakan orang-orang yang memiliki kemampuan, pengetahuan dan sikap yang dapat dijadikan pedoman bagi bawahan untuk mematuhi aturan yang dibuatnya dan mencontoh perilakunya. Kepemimpinan transformasional membangun asumsi bahwa setiap orang dapat dipercaya dan masing-masing individu mempunyai maksud dan tujuan tertentu (Bass dan Avolio, 1994). House (dalam Yulk, 1989) mengemukakan bahwa sifat yang secara umum dimiliki oleh pemimpin kharismatik adalah memiliki kepercayaan diri, memiliki rasa percaya terhadap bawahan, menaruh harapan besar terhadap bawahannya, memiliki visi dan menjadikan dirinya sebagai contoh personal bagi bawahannya. Bass, 1990 (dikutip Locke, 1991) melakukan pengkajian terhadap 40 penelitian yang ada dan hampir semua hasil penelitian menunjukkan adanya hubungan antara rasa percaya diri dengan kepemimpinan. Hasil temuan juga mengindikasikan bahwa pemimpin yang memiliki percaya diri akan mempunyai sikap tegas dan meyakinkan, sehingga membantu menimbulkan rasa percaya diri pengikutnya dalam berbagai keputusan yang diambil.

Perilaku pemimpin yang dapat menimbulkan image positif kepada bawahan merupakan salah satu faktor penting yang dapat menimbulkan rasa simpati bawahan terhadap pemimpinnya. Menurut Bennis dan Nanus (1985), para pemimpin berusaha mengimpresikan gayanya secara personal. Dengan demikian diharapkan para bawahan memiliki model dalam melakukan aktivitasnya dengan melihat pemimpinnya yang atraktif, sukses dan kompeten. Conger dan Kanungo (1987) berpendapat bahwa pemimpin hendaknya menciptakan komitmen image personal secara total sehingga bawahan menjadi kreatif dan berani mengambil resiko. Image yang baik yang ditimbulkan pemimpin dapat menciptakan rasa simpatik bawahan terhadap perilaku pemimpin. Behling dan McFillen (1996) mengungkapkan bahwa awe bawahan disebabkan oleh projects self-assurance dan enhances the leader's image dari perilaku pemimpin. Berdasarkan uraian diatas, peneliti mengajukan hipotesis sebagai berikut:

Hipotesis 2a : Projects self-confidence dari perilaku pemimpin berpengaruh secara signifikan terhadap awe bawahan.

Hipotesis $2 \mathrm{~b}$ : Enhances the leader's image dari perilaku pemimpin berpengaruh secara signifikan terhadap awe bawahan.

\section{2. Assures Followers of Their Competency, Provides Opportunities for Followers to Experience Success, dan Empowerment}


Pemberdayaan bawahan diharapkan dapat meningkatkan kinerja karyawan secara optimal melalui koordinasi dan pengarahan dari pemimpin. Behling dan McFillen (1996) memberikan definisi operasional mengenai variabel perilaku pemimpin (the followers of their competency dan provides followers with opportunities to experience success) dan variabel keyakinan bawahan (empowerment) sebagai berikut:

a. Assures followers of their competency, yaitu pemimpin bersikap untuk menyampaikan gagasan bahwa bawahan dapat meningkatkan kinerjanya, mengatasi hambatan, dan mengendalikan dituasi di sekitar mereka.

b. Provides followers with opportunities to experience success, yaitu pemimpin mendelegasikan tanggung jawab untuk memberi tantangan tugas dan pekerjaan sehingga merubah hambatan menjadi kinerja bawahan.

c. Empowerment, yaitu keyakinan bawahan terhadap kemampuannya sendiri dalam organisasi atau unit di mana mereka menjadi bagian untuk mengatasi hambatan dan mengendalikan situasi.

Dalam kepemimpinan transformasional, pemimpin akan berupaya menciptakan iklim yang kondusif bagi perkembangan inovasi dan kreativitas. Kepemimpinan transformasional merupakan suatu tipe pemimpin yang memberikan inspirasi dan rangsangan intelektual pada masing-masing pengikutnya serta memiliki kharisma terhadap pengikutnya (Koontz, O'Donnell \& Weihrich, 1986). Esensi dari kepemimpinan transformasional adalah sharing of power melibatkan bawahan secara bersama-sama untuk melakukan perubahan dan memfasilitasi pengembangan individu untuk merealisasikan potensi dirinya (Handoko \& Tjiptono, 1996). Dalam konsep kepemimpinan transformasional, tugas seorang pemimpin adalah berupaya memotivasi bawahannya agar dapat berprestasi melampaui harapan dan perkiraan sebelumnya. Dengan kata lain bahwa pemimpin dapat secara signifikan menguatkan keyakinan bawahan pada kemampuan dirinya sendiri, sehingga dengan sense of self-efficacy yang lebih kuat maka para karyawan akan lebih mampu bekerja dan berhasil dalam melakukan berbagai hal yang menantang. Ford dan Fottler (1995) mengatakan bahwa pemberdayaan sangat diperlukan untuk membangun hubungan interpersonal agar terjalin hubungan saling mempercayai antara pemimpin dengan para karyawan. Hubungan ini menjadikan individu cenderung berusaha melakukan perbaikan terus menerus dalam kualitas, produktivitas dan pelayanan. Seorang pemimpin transformasional juga memberikan inspirasi kepada bawahannya, bekerjasama secara individual dengan bawahan untuk memenuhi kebutuhan yang meningkat, mendorong penggunaan pendekatan baru, dan pemecahan masalah secara cermat, menciptakan kinerja superior dengan membangun pembagian tanggung jawab kelompok, mengembangkan secara terus menerus ketrampilan bawahannya, dan membangun visi departemental secara umum (Bass, 1990). Tipe kepemimpinan seperti ini akan menimbulkan kepercayaan bawahan terhadap pemimpin dan menimbulkan asumsi bahwa setiap orang dapat dipercaya sehingga kesenjangan hubungan antara pemimpin dengan bawahan tidak akan terjadi lagi namun muncul suatu hubungan baru bahwa atasan adalah patner bagi bawahan yang akan membantu dalam mengatasi setiap hambatan dan bekerja bersama-sama untuk mewujudkan tujuan organisasi.

Conger dan Kanungo (1988) membahas mengenai pemberdayaan bawahan yang berarti terdapat manajemen partisipasi, penentuan tujuan, umpan balik, model, penghargaan dan job enrichment pemberdayaan bawahan melalui pemberian kesempatan untuk sukses kepada bawahan. Pemimpin yang dapat merubah hambatan menjadi kinerja yang bagus akan meningkatkan kesuksesan dan kepercayaan diri bawahan. Behling dan McFillen (1996) mengungkapkan bahwa empowerment bawahan disebabkan oleh assures followers of their competency dan provides opportunities for followers to experience success dari perilaku pemimpin. Berdasarkan uraian diatas, peneliti mengajukan hipotesis sebagai berikut:

Hipotesis 3a : Assures followers of their competency dari perilaku pemimpin berpengaruh secara signifikan terhadap pemberdayaan (empowerment) bawahan

Hipotesis 3b: Provides opportunities for followers to experience success dari perilaku pemimpin berpengaruh secara signifikan terhadap pemberdayaan (empowerment) bawahan

\section{3. MODEL PENELITIAN: MODEL SYNCRETICAL}

Penelitian ini dilakukan untuk menguji model syncretical kepemimpinan kharismatik/ transformasional yang dikemukakan oleh Behling dan McFillen (1996) pada penelitian terdahulu. Model 
syncretical merupakan suatu model yang mengkombinasikan gagasan-gagasan dari berbagai tulisan yang ada mengenai kepemimpinan kharismatik/transformasional ke dalam hubungan kausal dan moderating. Dalam pembuatan model syncretical ini, Behling dan McFillen menggunakan seluruh aspek perilaku pemimpin dan keyakinan bawahan untuk melihat hubungan antar variabel dalam pengujian empiris. Kedua peneliti juga mencoba mengembangkan instrumen pengukuran atribut perilaku pemimpin dan keyakinan kunci bawahan yang pada akhirnya akan mempengaruhi perilaku bawahan.

Model syncretical kepemimpinan kharismatik/transformasional terdiri dari tiga buah model secara terpisah dan masing-masing model tersebut akan diuji dalam penelitian ini. Penelitian ini diarahkan untuk menjawab tiga pertanyaan sebagai jawaban atas ketiga hipotesis yang diajukan oleh peneliti sebelumnya yaitu mengenai pengaruh atribut perilaku pemimpin (terdiri dari displays empathy, dramatizes the mission, projects self-assurance, enhances the leader's image, assures followers of competency, dan provides opportunities to experience success) terhadap keyakinan kunci bawahan (terdiri dari inspiration, awe dan empowerment) dengan menggunakan instrumen penelitian yang telah dikembangkan oleh kedua peneliti tersebut (gambar 1). Sesuai dengan hal tersebut, maka phisic distress sebagai variabel pemoderasi antara atribut perilaku pemimpin terhadap keyakinan bawahan dan attributes of followers behavior tidak diteliti dalam penelitian ini (gambar 2). Dalam penelitian sebelumnya, Behling dan McFillen membatasi pengisian kuesioner bagi responden yang diarahkan pada perasaan responden selama tujuh hari terakhir dari pengisian kuesioner sehingga prosedur yang sama juga diterapkan bagi responden dalam penelitian ini.

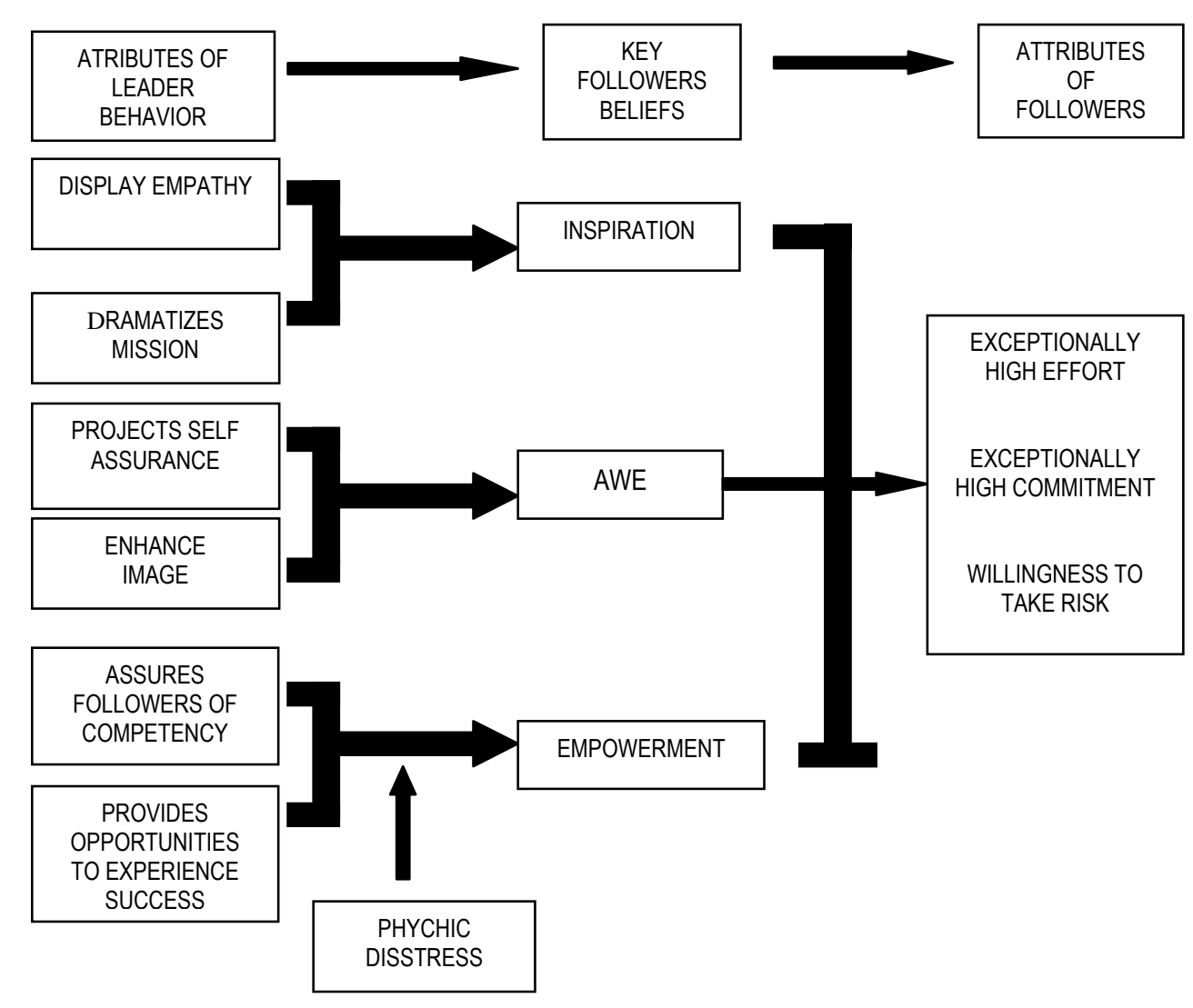

Sumber: Behling, O. \& McFillen, J.M. (1996), p. 166

\section{Gambar 1. Model Syncretical Kepemimpinan Kharismatik/Transformasional}




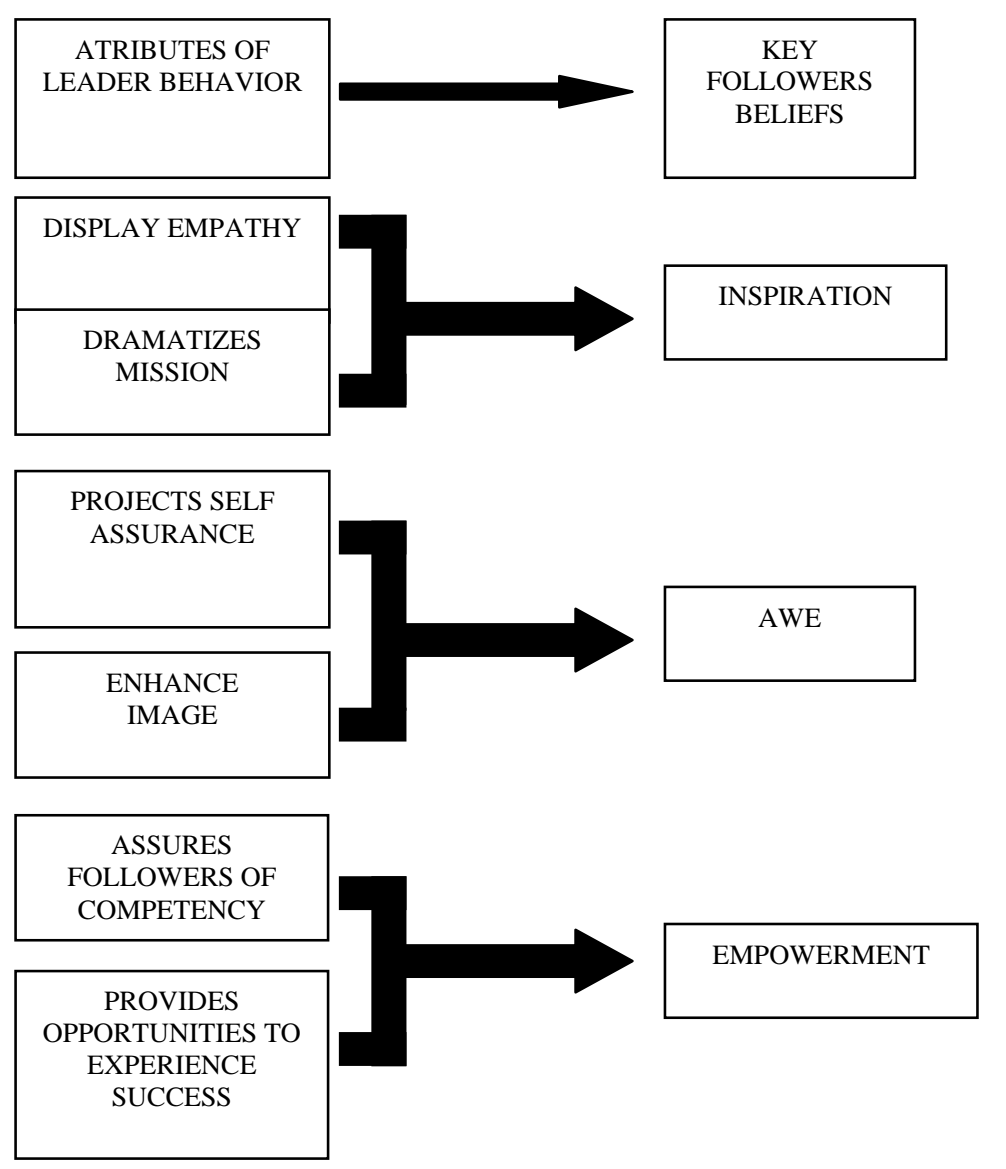

Sumber: Behling, O. \& McFillen, J.M. (1996), p. 166

\section{Gambar 2. Model Penelitian Yang Akan Digunakan}

\section{METODOLOGI PENELITIAN}

\section{1. Sampel Penelitian}

Obyek dalam penelitian ini adalah mahasiswa program Magister Manajemen (MM) pada 3 Perguruan Tinggi negeri dan swasta di Daerah Istimewa Yogyakarta yaitu Universitas Gadjah Mada (UGM), Universitas Atma Jaya (UAJY) dan Universitas Islam Indonesia (UII). Responden yang dipilih sebagai sampel adalah mahasiswa MM di tiga universitas tersebut yang telah bekerja baik di instansi pemerintah maupun swasta. Kriteria yang digunakan dalam pemilihan responden adalah bahwa selama menjadi mahasiswa (studi di MM), responden masih tetap aktif bekerja sehingga responden dapat merasakan interaksi antara pemimpin dengan bawahan sehingga responden dapat melakukan penilaian dan menjawab pertanyaan kuesioner yang difokuskan pada perasaan responden selama 7 hari.

Response rate penelitian ini diperoleh sebanyak 95\% (162 responden) dari total sampel yang digunakan (172 responden). Hasil penyebaran kuesioner menunjukkan bahwa 43 kuesioner tidak dapat digunakan sehingga responden potensial diperoleh sebanyak 119 responden. Mayoritas responden terdiri dari responden pria sebesar 116 orang (81\%), 84 orang (71\%) merupakan karyawan swasta, 69 orang (58\%) mempunyai pengalaman kerja lebih dari 6 tahun dan 45 orang (38\%) mempunyai umur antara 38 sampai 44 tahun. 


\section{2. Metode Pengumpulan Data}

Metode pengumpulan data dilakukan dengan survey atau melakukan penyebaran kuesioner (daftar pertanyaan) kepada responden. Kuesioner yang digunakan dalam penelitian ini terdiri dari 2 buah kuesioner yaitu Follower Belief Questionnaire-Form I dan Attribute of Leader Behavior Questionnaire-Form II yang dikembangkan oleh Behling dan McFillen (1996). Metode penyebaran kuesioner dilakukan dengan dua cara yaitu secara langsung dan secara tidak langsung sesuai dengan peraturan dan ketentuan dari universitas yang bersangkutan. Kedua kuesioner tersebut diisi oleh Mahasiswa MM di Universitas Gadjah Mada (UGM), Universitas Atma Jaya (UAJY) dan Universitas Islam Indonesia (UII) yang telah bekerja baik di instansi pemerintah maupun swasta. Penyebaran kuesioner dilakukan mulai akhir bulan Januari 2001 sampai dengan awal bulan Maret 2001.

\section{2. 1. Pengukuran Variabel}

Variabel perilaku pemimpin diukur dengan Attribute of Leader Behavior Questionnaire-Form II (Behling \& McFillen, 1996) yang terdiri dari 18 item pertanyaan sehingga masing-masing variabel perilaku pemimpin mempunyai 3 item pertanyaan dengan lima skala likert yang mempunyai bobot dari 5 sampai dengan 1, dengan alternatif jawaban dari sangat setuju (SS), setuju (S), netral (N), tidak setuju (TS), dan sangat tidak setuju (STS).

Variabel keyakinan bawahan diukur dengan Follower Belief Questionnaire-Form I (Behling \& McFillen, 1996) yang terdiri dari 15 item pertanyaan sehingga masing-masing variabel keyakinan bawahan mempunyai 5 item pertanyaan dengan lima skala likert yang mempunyai bobot dari 5 sampai dengan 1 , dengan alternatif jawaban dari sangat setuju (SS), setuju (S), netral (N), tidak setuju (TS), dan sangat tidak setuju (STS). Jawaban untuk variabel perilaku pemimpin dan variabel keyakinan bawahan ini diarahkan untuk perasaan bawahan selama 7 hari terakhir dari pengisian kuesioner.

\section{2. 2. Uji Validitas dan Reliabilitas}

Uji validitas dan uji reliabilitas dilakukan untuk mengetahui kualitas item-item pertanyaan dari kuesioner yang akan digunakan dalam suatu penelitian. Uji validitas dilakukan dengan perhitungan factor analysis terhadap item-item kuesioner dengan menggunakan program statistik SPSS for windows release 9.0. dengan menggunakan principal components analysis. Hasil analisis faktor menunjukkan bahwa masingmasing item pertanyaan dari 6 variabel perilaku pemimpin dan 3 variabel keyakinan bawahan mempunyai faktor loading diatas 0,40 sehingga dapat dikatakan bahwa item-item pada kuesioner I dan kuesioner II memiliki tingkat validitas yang memadai dan valid sebagai instrumen penelitian.

Uji reliabilitas diukur dengan menggunakan koefisien alpha (cronbach alpha) dari hasil perhitungan dengan menggunakan program statistik SPSS release 9.0. dengan a di atas 0,60. Suatu instrumen penelitian dikatakan reliabel jika mempunyai nilai koefisien alpha (cronbach's alpha) di atas 0,60 (Sekaran, 1992; Cooper dan Emory, 1995). Hasil uji reliabilitas dalam penelitian ini menunjukkan bahwa 6 variabel perilaku pemimpin dan 3 variabel keyakinan bawahan memiliki nilai koefisien alpha (a) di atas 0,60 . Hasil tersebut menunjukkan bahwa kuesioner penelitian ini reliabel sebagai instrumen penelitian.

\section{3. Metode Analisis Data}

Pengujian hipotesis dilakukan dengan analisis regresi berganda untuk mengetahui pengaruh variabel perilaku pemimpin (independent variable) terhadap variabel keyakinan bawahan (dependent variable). Model syncretical yang diuji dalam penelitian ini terdiri dari tiga model secara terpisah dan masing-masing model akan diuji dengan menggunakan analisis regresi berganda.

\section{HASIL PENELITIAN DAN PEMBAHASAN}

Penelitian ini dilakukan untuk menguji model syncretical mengenai pengaruh perilaku pemimpin terhadap keyakinan bawahan yang terdiri dari tiga model secara terpisah dengan menggunakan analisis regresi berganda (Multiple Regression Analysis).

\section{1. Uji Hipotesis 1a dan 1b (Model 1)}


Analisis regresi berganda terhadap model pertama dilakukan untuk menguji hipotesis $1 \mathrm{a}$ dan $1 \mathrm{~b}$ mengenai pengaruh displays empathy (X1) dan dramatizes the mission (X2) dari perilaku pemimpin terhadap inspiration bawahan $(\mathrm{Y})$.

Tabel 1

Hasil Analisis Regresi Berganda untuk Inspiration

\begin{tabular}{lrlll}
\hline \multicolumn{1}{c}{ Variabel Independent } & $\boldsymbol{\beta}$ & $\mathbf{t}$ & \multicolumn{1}{c}{ Sig t } & $\mathbf{R}^{\mathbf{2}}$ \\
\hline & & & & \\
Displays Empathy (X1) & 0.522 & 3.469 & $0.001^{* *}$ & 0.106 \\
Dramatizes the mission (X2) & 0.152 & 1.010 & 0.315 & \\
Konstanta & 11.926 & 4.705 & 0.000 & \\
\hline$+p<0.10 ;{ }^{*} p<0.05 ;{ }^{* *} p<0.025$ & & & &
\end{tabular}

Hasil analisis regresi berganda terhadap model pertama menunjukkan bahwa variabel $\mathrm{X} 1$ signifikan pada $p<0.025$, sedangkan variabel X2 tidak signifikan. Hal ini berarti bahwa inspirations hanya dipengaruhi oleh variabel displays empathy (X1), tetapi tidak dipengaruhi oleh variabel dramatizes the mission (X2). Nilai koefisien determinasi atau $R$ square untuk variabel inspiration adalah sebesar 0,106, artinya bahwa 10,6\% variasi variabel inspiration dijelaskan oleh kedua variabel independen tersebut yaitu displays empathy dan dramatizes the mission. Hasil analisis ini menunjukkan dukungan terhadap hipotesis 1a, bahwa displays empathy dari perilaku pemimpin mempunyai pengaruh signifikan terhadap inspiration bawahan, namun hasil tidak menunjukkan dukungan terhadap hipotesis $1 \mathrm{~b}$ bahwa dramatizes the mission dari perilaku pemimpin tidak mempunyai pengaruh signifikan terhadap inspiration bawahan. Hal ini menunjukkan bahwa tinggi atau rendahnya dramatizes the mission dari perilaku pemimpin tidak berpengaruh secara signifikan terhadap inspirations bawahan.

\section{2. Uji Hipotesis $2 a$ dan $2 b$ (Model 2)}

Analisis regresi berganda terhadap model kedua dilakukan untuk menguji hipotesis $2 a$ dan $2 b$ mengenai pengaruh projects self assurance $(X 1)$ dan enhances the leader's image (X2) dari perilaku pemimpin terhadap awe bawahan $(\mathrm{Y})$.

Tabel 2

Hasil Analisis Regresi Berganda untuk Awe

\begin{tabular}{lcccc}
\hline Variabel Independent & $\boldsymbol{\beta}$ & $\mathbf{t}$ & Sig t & $\mathbf{R}^{\mathbf{2}}$ \\
\hline & & & & \\
Projects Self Assurance (X1) & 0.345 & 3.330 & $0.001^{* *}$ & 0.170 \\
Enhances The Leader's Image (X2) & 0.419 & 2.966 & $0.004^{* *}$ & \\
Konstanta & 8.193 & 4.369 & 0.000 & \\
\hline
\end{tabular}

$+p<0.10 ;{ }^{*} p<0.05 ;{ }^{* *} p<0.025$

Hasil analisis regresi berganda terhadap model kedua menunjukkan bahwa variabel $\mathrm{X} 1$ signifikan pada $p<0.025$ dan variabel X2 juga signifikan pada $p<0.025$. Ini berarti bahwa awe dipengaruhi oleh variabel projects self assurance (X1) dan enhances the leader's image (X2). Nilai koefisien determinasi atau $R$ square untuk variabel awe adalah 0,170 , artinya bahwa $17 \%$ variasi variabel awe dijelaskan oleh variabel projects self assurance dan enhances the leader's image. Hasil analisis regresi menunjukkan dukungan terhadap hipotesis $2 a$ dan $2 b$, yaitu bahwa project self assurance dari perilaku pemimpin mempunyai pengaruh signifikan terhadap awe bawahan dan bahwa enhance the leader's image dari perilaku pemimpin mempunyai pengaruh signifikan terhadap awe bawahan. 


\section{3. Uji Hipotesis 3a dan 3b (Model 3)}

Analisis regresi berganda terhadap model ketiga dilakukan untuk menguji hipotesis $3 a$ dan $3 b$ mengenai pengaruh assures followers of their competency $(\mathrm{X} 1)$ dan provides opportunities to experience success $(\mathrm{X} 2)$ dari perilaku pemimpin terhadap empowerment bawahan $(\mathrm{Y})$.

Tabel 3

Hasil Analisis Regresi Berganda untuk Empowerment

\begin{tabular}{llccc}
\hline Variabel Independent & $\boldsymbol{\beta}$ & $\mathbf{t}$ & $\mathbf{S i g} \mathbf{~}$ & $\mathbf{R}^{\mathbf{2}}$ \\
\hline & & & & \\
Assures Followers of Competency (X1) & 0.250 & 1.692 & $0.093+$ & 0.201 \\
Provides Opportunities to Experience & & & $0.000^{* *}$ & \\
Success (X2) & 0.892 & 4.692 & 0.029 & \\
Konstanta & 5.896 & 2.208 & & \\
\hline$+p<0.10 ;{ }^{*} p<0.05 ;{ }^{* *} p<0.025$ & & &
\end{tabular}

Hasil analisis regresi berganda terhadap model ketiga menunjukkan bahwa variabel X1 signifikan pada $p<0.10$ dan variabel $\mathrm{X} 2$ signifikan pada $p<0.025$. Ini berarti bahwa empowerment dipengaruhi oleh variabel assures followers of their competency (X1) dan provides opportunities to experience success (X2). Nilai koefisien determinasi atau $R$ square untuk variabel empowerment adalah sebesar 0,201 , artinya bahwa $20,1 \%$ variasi variabel empowerment dijelaskan oleh kedua variabel independen yaitu variabel assures followers of their competency dan provides opportunities to experience success. Hasil analisis regresi menunjukkan dukungan terhadap hipotesis $3 a$ dan $3 \mathrm{~b}$, yaitu bahwa assures followers of their competency dari perilaku pemimpin mempunyai pengaruh signifikan terhadap empowerment bawahan dan bahwa provides opportunities to experience success dari perilaku pemimpin mempunyai pengaruh signifikan terhadap empowerment bawahan

\section{PEMBAHASAN}

\section{1. Displays Empathy, Dramatizes the mission dan Inspiration}

Hasil analisis terhadap model pertama menunjukkan dukungan terhadap hipotesis 1a bahwa displays empathy dari perilaku pemimpin mempunyai pengaruh signifikan terhadap inspiration bawahan, namun hasil analisis tidak menunjukkan dukungan terhadap hipotesis $1 \mathrm{~b}$ yaitu bahwa dramatizes the mission dari perilaku pemimpin tidak berpengaruh secara signifikan terhadap inspirations bawahan.

Didukungnya hasil pengujian terhadap hipotesis 1a menunjukkan bahwa hasil penelitian tersebut konsisten dengan penelitian Behling dan McFillen (1996) yang menyatakan bahwa displays empathy dari perilaku pemimpin mempunyai pengaruh signifikan terhadap inspiration bawahan. Ini berarti bahwa pemimpin yang memiliki empathy terhadap bawahan akan meningkatkan kepercayaan bawahan terhadap aktivitas organisasi sehingga pada akhirnya bawahan akan terinspirasi untuk bekerja secara optimal. Hal ini sesuai dengan pendapat Davis (1972) yang menyebutkan bahwa ada empat ciri utama yang berpengaruh terhadap kesuksesan pemimpin dalam organisasi, yaitu kecerdasan (intelegence), kedewasaan dan hubungan sosial, motivasi diri dan dorongan berprestasi, dan memiliki sikap hubungan manusiawi dimana pemimpin yang sukses akan menghargai bawahan, mempunyai perhatian tinggi dan berorientasi kepada bawahannya. Hasil penelitian Fatom Ahmad, 1966 (seperti dikutip oleh As'ad, 1986) menemukan bahwa sikap pemimpin yang ramah tamah, penuh perhatian dan pengertian namun dapat bersikap tegas terhadap bawahan lebih mendorong semangat kerja bawahan sehingga dapat meningkatkan produktivitas kerjanya. Hal ini dapat diartikan bahwa pemimpin yang mempunyai empati terhadap bawahan akan menimbulkan inspirasi kepada bawahan untuk bekerja secara optimal sehingga akan menghasilkan produktivitas kerja yang tinggi.

Tidak didukungnya hasil pengujian terhadap hipotesis $1 \mathrm{~b}$ menunjukkan bahwa hasil penelitian tersebut tidak konsisten dengan penelitian sebelumnya dari Behling dan McFillen (1996) yang menyatakan bahwa dramatizes mission dari perilaku pemimpin berpengaruh secara signifikan terhadap inspiration 
bawahan. Tidak didukungnya hipotesis $1 \mathrm{~b}$ ini menunjukkan bahwa hasil tersebut tidak sesuai dengan pendapat Leavitt (1986) yang mengemukakan bahwa kesuksesan kepemimpinan transformasional adalah kemampuan menentukan misi yang jelas, mengkomunikasikannya dan melakukan persuasi kepada bawahan. Bass (1990) juga mengungkapkan bahwa seorang pemimpin transformasional memiliki kharisma yaitu pemimpin mempunyai visi dan sense of mission, sangat memperhatikan kebutuhan karyawan, mau menanggung resiko bersama, dan tidak menggunakan kekuasaan untuk kepentingan pribadi. Perilaku pemimpin seperti ini akan mendapatkan perhatian, kepercayaan, dan loyalitas dari bawahan, serta mendapat pengidentifikasian yang kuat dari bawahannya. Hal ini akan menghasilkan antusiasme, kebanggaan pada diri sendiri dan tujuan, sehingga bawahan akan terispirasi untuk melakukan hal yang sama sebagaimana yang dilakukan oleh pemimpin mereka.

Tidak didukungnya hipotesia $1 \mathrm{~b}$ bisa disebabkan karena penelitian ini dilakukan pada setting budaya yang berbeda dari penelitian sebelumnya dimana berbagai faktor baik internal maupun eksternal seperti kondisi sosial, kultur/ budaya organisasi, desain organisasi dan gaya manajemen akan sangat berpengaruh dalam membentuk pola perilaku dan sikap individu dalam berorganisasi. Hasil riset kepemimpinan lintas budaya yang dilakukan Jung dan Avolio (1999) terhadap 153 Asean student dan 194 Caucasian student mengenai kepemimpinan transformasional dan transaksional mengindikasikan bahwa penerapan gaya kepemimpinan yang sama dapat diinterpretasikan berbeda dan dapat mempunyai pengaruh yang berbeda dalam motivasi dan kinerja bagi bawahan pada kelompok budaya yang berbeda. Kenyataan yang banyak terjadi di Amerika adalah bahwa kesadaran para pekerja (karyawan) di negara tersebut terhadap visi dan misi perusahaan sudah sangat tinggi dimana masing-masing individu sudah mempunyai idealisme yang sangat tinggi dalam bekerja sehingga mereka mempunyai keberanian untuk menolak pekerjaan dari perusahaan yang tidak mempunyai visi dan misi yang jelas. Hal seperti ini akhirnya akan membuat para pemimpin juga menyadari akan pentingnya penyampaian visi dan misi kepada bawahan. Berbeda dengan di Amerika, kenyataan yang seringkali terjadi di berbagai perusahaan di Indonesia menunjukkan bahwa penyampaikan visi dan misi kepada bawahan masih dianggap sebagai hal yang kurang penting sehingga sering terjadi bahwa misi perusahaan masih dianggap sebagai slogan semata baik bagi pemimpin maupun bawahan. Baik pemimpin maupun karyawan belum menempatkan visi dan misi perusahaan sebagai faktor krusial sebagai penentu arah dan tujuan dalam beorganisasi sehingga seringkali terjadi bahwa visi dan misi tersebut hanya diketahui bawahan melalui tulisan-tulisan yang ada di perusahaan atau melalui rekan kerja mereka. Hal ini pada akhirnya akan membuat bawahan tidak memahami arah dan tujuan organisasi secara jelas sehingga rasa memiliki dan rasa tanggung jawab terhadap perusahaan juga berkurang.

Kemungkinan lain tidak didukungnya hipotesis $1 \mathrm{~b}$ tersebut dapat juga disebabkan karena sampel yang digunakan dalam penelitian ini (78\% responden) adalah mahasiswa MM yang pada umumnya telah memiliki jabatan di perusahaannya sehingga perhatian mereka lebih terfokus pada pekerjaan dan mempertahankan jabatan seperti yang telah mereka dapatkan selama ini. Sementara itu, para pemimpin sendiri lebih memfokuskan perhatian pada kinerja karyawan dimana pemimpin akan berusaha membuat karyawan bekerja sebaik mungkin agar perusahaan dapat terus bertahan dalam kondisi persaingan yang sangat tinggi. Kondisi seperti ini mengakibatkan tugas pemimpin dalam penyampaian visi dan misi organisasi/perusahaan menjadi terabaikan.

\section{2. Projects self-assurance, Enhances the leader's image dan Awe}

Hasil analisis terhadap model kedua menunjukkan dukungan terhadap hipotesis $2 \mathrm{a}$ dan $2 \mathrm{~b}$ yaitu bahwa projects self-assurance dari perilaku pemimpin berpengaruh secara signifikan terhadap awe bawahan dan bahwa enhances the leader's image dari perilaku pemimpin berpengaruh secara signifikan terhadap awe bawahan. Hasil penelitian ini konsisten dengan penelitian sebelumnya (Behling dan McFillen, 1996) yang menyatakan bahwa projects self-assurance dan enhances the leader's image dari perilaku pemimpin mempunyai pengaruh signifikan terhadap awe bawahan. Ini berarti bahwa rasa simpati bawahan terhadap pemimpin akan sangat dipengaruhi oleh perilaku pemimpin yang dapat menunjukkan rasa percaya diri yang tinggi dan dapat menunjukkan image positif terhadap bawahan yang terpancar pada berbagai aspek, baik dari aspek pekerjaan maupun kemampuannya berorganisasi. Willner (1984) menyatakan bahwa dimensi 
kepemimpinan kharismatik meliputi kepercayaan bahwa pemimpin adalah orang yang hebat, mempunyai kekuasaan dan kemampuan, artinya bahwa pemimpin merupakan orang-orang yang memiliki kemampuan, pengetahuan dan sikap yang dapat dijadikan pedoman bagi bawahan untuk mematuhi aturan yang dibuatnya dan mencontoh perilakunya.

Pendapat Wilner tersebut sesuai dengan pendapat House (dalam Yulk, 1989) yang mengemukakan bahwa sifat yang secara umum dimiliki oleh pemimpin kharismatik adalah memiliki kepercayaan diri, memiliki rasa percaya terhadap bawahan, menaruh harapan besar terhadap bawahannya, memiliki visi dan menjadikan dirinya sebagai contoh personal bagi bawahannya. Bass dan Avolio (1994) juga mengemukakan bahwa kepemimpinan transformasional membangun asumsi bahwa setiap orang dapat dipercaya dan masing-masing individu mempunyai maksud dan tujuan tertentu. Dengan keyakinan diri dan sikap percaya diri yang tinggi maka pemimpin akan mendapatkan kepercayaan bawahan sehingga bawahan akan memiliki rasa simpati terhadap tindakan-tindakan yang dilakukan oleh pemimpinnya dan termotivasi untuk bekerja secara optimal.

\section{3. Assures followers of their competency, Provides opportunities for followers to experience success, dan Empowerment.}

Hasil pengujian terhadap model ketiga menunjukkan dukungan terhadap hipotesis 3a dan 3b yaitu bahwa assures followers of their competency dari perilaku pemimpin berpengaruh secara signifikan terhadap empowerment bawahan dan bahwa provides opportunities for followers to experience success dari perilaku pemimpin berpengaruh secara signifikan terhadap empowerment bawahan. Hasil penelitian ini konsisten dengan penelitian Behling dan McFillen (1996) yang menyatakan bahwa assures followers of their competency dan provides opportunities for followers to experience success dari perilaku pemimpin mempunyai pengaruh signifikan terhadap empowerment bawahan.

Didukungnya hasil pengujian terhadap hipotesis $3 a$ dan $3 b$ ini menunjukkan bahwa dalam kepemimpinan transformasional, seorang pemimpin berusaha menciptakan upaya pemberdayaan bagi bawahan serta menciptakan iklim yang kondusif bagi perkembangan inovasi dan kreatifitas. Hasil penelitian ini konsisten dengan pendapat Koontz, O'Donnell dan Weihrich (1986) yang mengatakan bahwa kepemimpinan transformasional merupakan suatu tipe pemimpin yang memberikan inspirasi dan rangsangan intelektual pada masing-masing pengikutnya serta memiliki kharisma terhadap pengikutnya. Esensi dari kepemimpinan transformasional adalah sharing of power melibatkan bawahan secara bersama-sama untuk melakukan perubahan dan memfasilitasi pengembangan individu untuk merealisasikan potensi dirinya (Handoko \& Tjiptono, 1996). Pemberdayaan sangat diperlukan untuk membangun hubungan interpersonal agar terjalin hubungan saling mempercayai antara pemimpin dengan para karyawan (Ford dan Fottler, 1995). Dalam konsep pemberdayaan, bawahan diberi wewenang dan tanggung jawab yang lebih besar dalam pengambilan keputusan sehingga komunikasi atau sharing informasi dan pengetahuan antara pemimpin dan bawahan merupakan faktor penting yang sangat dibutuhkan sehingga bawahan akan benar-benar memahami dan mengerti tugasnya dan selanjutnya mereka dapat memberikan kontribusi nyata dalam pencapaian tujuan dan keberhasilan organisasi (Behling dan McFillen, 1996). Tipe kepemimpinan seperti ini akan menimbulkan kepercayaan bawahan terhadap pemimpin dan menimbulkan asumsi bahwa setiap orang dapat dipercaya sehingga kesenjangan hubungan antara pemimpin dengan bawahan tidak akan terjadi lagi namun muncul suatu hubungan baru bahwa atasan merupakan patner bagi bawahan yang akan membantu dalam mengatasi setiap hambatan dan bekerja bersama-sama untuk mewujudkan tujuan organisasi.

\section{KESIMPULAN DAN KETERBATASAN \\ 6. 1. Kesimpulan}

Hasil analisis regresi berganda terhadap model pertama menunjukkan bahwa displays empathy dari perilaku pemimpin berpengaruh secara positif dan signifikan terhadap inspiration bawahan $(b=0,522 ; t=$ 3,469; $p<0,025)$, sedangkan dramatizes the mission dari perilaku pemimpin tidak berpengaruh secara signifikan terhadap inspiration bawahan. Hasil analisis tersebut mendukung hipotesis 1a yang menyatakan bahwa displays empathy dari perilaku pemimpin berpengaruh secara signifikan terhadap inspiration bawahan, 
namun hasil analisis tidak mendukung hipotesis $1 \mathrm{~b}$ yaitu bahwa dramatizes the mission dari perilaku pemimpin tidak berpengaruh secara signifikan terhadap inspiration bawahan.

Hasil analisis regresi berganda terhadap model kedua menunjukkan bahwa projects self-assurance dari perilaku pemimpin berpengaruh secara positif dan signifikan terhadap awe bawahan $(b=0,345 ; t=3,330$; $p<0,025)$ dan hasil juga menunjukkan bahwa enhances the leader's image dari perilaku pemimpin berpengaruh secara positif dan signifikan terhadap awe bawahan $(b=0,419 ; t=2,966 ; p<0,025)$. Hasil analisis tersebut mendukung hipotesis 2a yang menyatakan bahwa projects self-assurance dari perilaku pemimpin berpengaruh secara signifikan terhadap awe bawahan dan mendukung hipotesis $2 \mathrm{~b}$ yang menyatakan bahwa enhance the leader's image dari perilaku pemimpin berpengaruh secara signifikan terhadap awe bawahan.

Hasil analisis regresi berganda terhadap model ketiga menunjukkan bahwa assures followers of their competency dari perilaku pemimpin berpengaruh secara positif dan signifikan terhadap empowerment bawahan $(b=0,250 ; t=1,692 ; p<0,10)$ dan hasil juga menunjukkan bahwa provides to experience success dari perilaku pemimpin berpengaruh secara positif dan signifikan terhadap empowerment bawahan $(b=$ $0,892 ; t=4,692 ; p<0,025)$. Hasil analisis tersebut mendukung hipotesis 3 a yang menyatakan bahwa followers of their competency dari perilaku pemimpin berpengaruh secara signifikan terhadap empowerment bawahan dan mendukung hipotesis $3 \mathrm{~b}$ yang menyatakan bahwa provides to experience success dari perilaku pemimpin berpengaruh secara signifikan terhadap empowerment bawahan.

\section{2. Keterbatasan Penelitian dan Saran Bagi Penelitian Mendatang}

Penelitian ini masih menggunakan subyek penelitian yang terbatas. Peneliti menggunakan mahasiswa MM di UGM (Universitas Gadjah Mada), UII (Universitas Islam Indonesia), dan UAJY (Universitas Atma Jaya) yang telah bekerja di suatu instansi/perusahaan sebâgai sampel penelitian dimana sebagian besar responden tersebut ternyata merupakan karyawan pada level menengah ke atas sehingga perlu kehatihatian dalam menginterpretasikan dan menggeneralisasikan hasil penelitian ini pada setting penelitian berbeda. Oleh karena itu, masih diperlukan penelitian terhadap model syncretical pada setting penelitian yang berbeda (misalnya dengan menggunakan sampel pada semua level organisasional di berbagai perusahaan) untuk mengetahui konsistensi dari hasil penelitian ini. Hal ini dilandasi oleh pendapat (Kouzes dan Posner, 1988; dalam Tjiptono dan Syakhroza, 1999) yang menyatakan bahwa kepemimpinan transformasional berlaku untuk semua level organisasi, bukan hanya pada level manajemen puncak. Untuk penelitian mendatang, peneliti dapat menguji model syncretical ini pada semua level di organisasi untuk mengetahui apakah model tersebut memang hanya berlaku untuk level tertentu atau dapat berlaku pada semua level organisasional.

Penelitian ini belum menggunakan model syncretical kepemimpinan kharismatik/transformasional secara lengkap dimana variabel physic disstress sebagai variabel pemoderasi antara pengaruh atribut perilaku pemimpin terhadap keyakinan bawahan dan attributes of followers behavior dalam model tersebut tidak diuji dalam penelitian ini. Penelitian ini hanya menguji model syncretical dengan memfokuskan pada pengaruh atribut perilaku pemimpin dan keyakinan bawahan yang didasarkan pada ketiga hipotesis yang telah diajukan pada penelitian terdahulu dengan menggunakan instrumen penelitian yang dihasilkan Behling dan McFillen (1996) tersebut. Tidak dilakukannya pengujian terhadap variabel physic disstress dan attributes of followers behavior dalam model tersebut karenakan bahwa peneliti belum menemukan adanya instrumen untuk mengukur variabel-variabel tersebut. Penelitian mendatang hendaknya mempertimbangkan variabel-variabel tersebut sehingga penelitian mendatang merupakan pengembangan yang lebih baik dari penelitian ini.

Tidak didukungnya hipotesis $1 \mathrm{~b}$ dimana variabel dramatizes the mission dari perilaku pemimpin tidak mempunyai pengaruh signifikan terhadap inspiration bawahan mungkin juga disebabkan karena permasalahan metodologi yaitu terjadinya common method bias yang sering terjadi dalam berbagai penelitian terutama penelitian yang berhubungan dengan sikap dan perilaku. Permasalahan tersebut terjadi pada saat responden harus memberikan jawaban terhadap seluruh item penyataan yang diajukan dalam suatu kuesioner, sehingga jawaban responden terhadap item pernyataan sebelumnya akan berpengaruh terhadap jawaban pada item pertanyaan berikutnya. 


\section{DAFTAR PUSTAKA}

As'ad, M., (1986), Kepemimpinan Efektif dalam Perusahaan: Suatu Pendekatan Psychologik, Liberty. Yogyakarta.

Bass, B.M., (1985), Leadership and Performance Beyond Expectation. New York: Free Press.

, (1990), "From Transactional to Transformational Leadership: Learning to Share The Vision", Journal of Organization Dynamics, 18(4): 19-31.

Bass, B.M., \& Avolio, B.J., (1990), Transformational Leadership Development: Manual for the Multifactor leadership Questionnaire. California: Consulting Psychologists Press.

\& Avolio, B.J., (1994), Improving Organizational Effectiveness Through Transformational Leadership. Thousand Oaks: SAGE Publications, Inc.

Behling, O., \& McFillen. J.M., (1996), "A Syncretical Model of Charismatic/ Transformational Leadership", Group \& Organizational Management, 21: 163-191.

Bennis, W., \& Nanus, B., (1985), Leaders: The Strategies for Taking Charge. New York: Harper \& Row.

Cohen, J., \& Cohen, P., (1983), Applied Multiple Regression/Correlation Analysis for The Behavioral Sciences. New Jersey: Erlbaum, Hillsdale.

Conger, J.A., \& Kanungo, R.N., (1987), "Toward a Behavioral Theory of Charismatic Leadership in Organizational Setting", Academy of Management Review, 12(4): 637-647.

Conger, J.A., \& Kanungo, R.N., (1988), "The Empowerment Process: Integrating Theory and Practice", Academy of Management Review, 13(3): 471-482.

Cooper, D.R., \& Emory, C.W., (1995), Business Research Methods, Fifth Edition. Chicago: Richard D. Irwin, Inc.

Ford, R.C., \& Fottler, M.D., (1995), Empowerment: A Matter of Degree. Academy of Management Executive, 9(3): 21-31.

Hair, J.F., Anderson, R.E., Tatham, R.L., \& Black, W.C., (1992), Multivariate Data Analysis with Readings. U.S.A.: Macmillan Publishing Company.

Handoko, H., \& Tjiptono, F., (1996), Kepemimpinan Transformasional dan Pemberdayaan. Jurnal Ekonomi dan Bisnis Indonesia. 1(1): 23-34.

Jung, D.I., \& Avolio, B.J., (1999), "Effects of Leadership Style and Followers' Cultural Orientation on Performance in Group and Individual Task Conditions", Academy of Management Journal, 42(2): 208-218. 
Koontz., O'Donnell., \& Weihrich., (1986), Essentials of Management, Fourth Edition, McGraw-Hill Book Company, USA.

Locke, E.A., (1991), The Essence of Leadership: The Four Keys to Leading Successfully. MacMillan, Inc.

Mulyadi, (1997), Atribut Leaders Masa Depan. Usahawan, TH XXVI(11): 28-32.

Sekaran, U., (1992), Research Methods for Business: A Skill Building Approach. Second edition, New York: John Wiley \& Sons, Inc.

Tjiptono, F. \& Syakhroza, A., (1999), Kepemimpinan Transformasional. Usahawan, TH XXIII (9): 5-13.

Vries, K.D., (1994), The Leader Mistique. Academy of management Executive, 8(3): 73-89.

Willner, A., (1984), The Spellbinders: Charismatic Political Leadership. New Haven, CT: Yale University Press.

Yukl, G.A., (1998), Leadership in Organization. Fourth Edition, London: Prentice-Hall International. 